\title{
Primates crop raiding situation on farmlands adjacent to South-West of Mole National Park, Ghana
}

\author{
E.D. WIAFE* \\ (E.D.W.: Presbyterian University College Ghana, Department of Environmental and \\ Natural Resources Management, P. O. Box 393, Akropong-Akuapem, Ghana) \\ *Corresponding author's email: edward.wiafe@presbyuniversity.edu.gh
}

\begin{abstract}
Human activities have led to the overlapping of resource requirements among themselves and animal species and this often results in conflict. This research was conducted to determine the type of animal species involved in crop raiding, crops raided, the reasons for crop raiding events with its associated effects on the livelihoods of surrounding communities and the mitigation measures against it. 10 victims from eight communities were interviewed through a semi-structured guide. Though many animals were involved, the most troublesome and destructive were the following monkey species: Olive baboons (Papio anubis); Patas monkeys (Erythrocebus patas); and Green monkeys (Cercocerbus sabaeus). These monkeys raiding events were found to be based on the palatability of crops and the most adopted methods used in deterring them were shouting and trapping. Monkeys were found to raid crops at the various farms in the communities for diverse reasons and recommendations for peaceful coexistence of humans have been made.
\end{abstract}

Keywords: crop raiding; primates; human-wildlife conflicts; human-wildlife coexistence; Mole National Park

Original scientific paper. Received 19 Jan 2019; revised 01 Oct 2019

\section{Introduction}

The conflict between humans and wildlife today undoubtedly ranks amongst the main threats to conservation of wildlife in Africa, in addition to hunting and habitat destruction. The adaptable nature of certain wildlife species (especially those that share common traits with humans), along with their ability to learn very rapidly and change their behaviour render them a very successful candidate to create conflict between humans that live closely with them (Else, 1991).

In a developing country like Ghana, where there is a high degree of dependence on agriculture for subsistence within communities, if wild animals consume crops meant for human consumption then conflict arises. On the other hand, if human beings expand their cultivated land into or close to wildlife habitat, crop raiding becomes one of the most common conflicts antagonizing human-wildlife relationships. The conflict accelerates as the human population keeps growing at a high rate with the invention of modern tools and equipment to encroach into land containing wildlife habitats (Hill, 2000; Allotey \& Wiafe, 2015).

Ghana Jnl Agric. Sci. 54 (2), 58 - 67

GJAS is an Open Access Journal and distributed under the terms of the Creative Commons (CC) License [CC BY 4.0] 
This kind of conflict has been recognized by the early artist and has been featured in some paintings e.g., a Diana monkey (Cercopithecus diana) among three monkeys stealing food by Franz Synder (1579 -1657) in Louvre-Paris, France (Grubb, 1998). San or Bushman rock art in Africa also sometimes presents people who flee from animal attack or some predators. Historians of pre-colonial and early 19th century described many cases in the world where large mammals especially elephants have raided human farms and agricultural areas, which consequently ended up in food shortages and subsequently displacement of settlements (Barnes, 1996).

Primates are group of wild animals ranking high among the species that cause damage to farmers' produce. This has probably been so because they have close lineages to humans and some of the primate species find crops palatable and their population normally grows in numbers to become pest (ForthmanQuick \& Demment, 1988). The losses incurred by farmers compel individuals and communities living close to primate range protected areas to develop antagonistic and intolerant relationship towards primates. Though many species of animals (e.g., insects, rodents, birds and livestock) raid cultivated crops, primates, in particular, can be significant pests because of their opportunism, adaptability, intelligence and manipulative abilities (Naughton-Treves, 1998; Sillero-Zubiri \& Switzer, 2001; Warren et al., 2007). For instance, in western Uganda, a study of the behaviour of non-human primates on farms identifies number of individuals raiding and duration of raids as primary parameters determining crop loss (Wallace \& Hill, 2012).

Attention has recently been given to human-elephant conflict around the Mole
National Park (MNP) (Akenten, 2015; Dakwa, 2016) however, the conflict between human and non-human primates has not been investigated in the area. Extensive studies have been conducted on human-primates interactions elsewhere in the Eastern African region such as Tanzania (Gillingham \& Lee, 2003), Uganda (Hill, 2000; 2004; NaughtonTreves et al., 1998; Saj et al., 2001), Zanzibar (Siex \& Struhsaker, 1999) and Kenya (de Jong et al., 2008). However, there are no systematic records or centralized databases on humanprimates conflict and for that matter, little information exists to verify exactly what is occurring around MNP in Northern Ghana. In recent times, there has been a public outcry on the destruction caused by non-human primates to the food of people living and farming on the piece of land situated between the southwestern border of MNP and northern border of Kanikani Forest Reserve.

This study, therefore, provides baseline information on human-primates conflicts and strategies adopted for coexistence. It specifically investigated the type of non-human primate species involved in crop raiding, type of crops being raided, the causes of crop raid, its effects on the livelihoods of surrounding reserves and the mitigation measure against crop raiding by non-human primates.

\section{Materials and methods}

\section{Study area}

The study took place on the piece of land that situates between the south-western part of the Mole National park and Kanikani forest reserve in Ghana (Figure 1). It is located in a fairly undisturbed portion of the Guinea Savannah zone in Northern Ghana and includes parts of West Gonja and Sawla-Tuna-Kalaba, and lies between latitudes $9^{\circ} 11^{\prime}$ and $10^{\circ} 10^{\prime} \mathrm{N}$, and 
longitudes $1^{\circ} 22^{\prime}$ and $2^{\circ} 13^{\prime} \mathrm{W}$. The climatic conditions of the area have two seasons: a dry season from November to April, and a rainy season from May to October. Annual rainfall is around $1100 \mathrm{~mm}$ per annum. The mean annual temperature is $27.8^{\circ} \mathrm{C}$, with extremes of $35^{\circ} \mathrm{C}$ to $40^{\circ} \mathrm{C}$ (Wilson, 1993).

\section{Data collection procedure}

The study was conducted in eight communities located at the south-western boundary of the Mole national park, in 2016. A minimum of 10 victims of farm raiding was selected from each of the communities on a $60 \mathrm{~km}$ stretch along the south-western boundary of Mole National Park. The selected communities were as follows: Kananto, Kabampe, Grupe, Seiyire, Nosoyire, Jintripe, Nyanye and Sawla (Figure 1). The sampled participants were selected based on the fact that the farmer had suffered crop raiding, not beyond one month from the period of the interview. Most of the victims engaged mainly in farming activities which is their sole source of livelihood. Maize, groundnut, millet sorghum, rice, yam, beans, mango and other crops were normally cultivated in the eight communities with an attachment of local poultry farming for subsistence. Participants who wanted to disclose their identity informed us and pseudo-names were used for those who wanted to remain anonymous. Each interviewee was subsequently informed that sensitive information and personal characteristics would not be included in the report of the study (Christensen, 1992). Participants were interviewed on types of crops, animals involved, effects and mitigation measures against crop raiding. Semi-structured interview guides were depended on for the interview. The framework for interviews was adapted from Gillingham and Lee (2003) and the Oxford Brookes University Code of
Practice on Ethical Standards was followed. Statistical Package for Social Scientists (SPSS v. 16) was used for analysis of the data.

The frequency of raids by primates was based on the number of times respondents had constantly observed the occurrence. The frequency of raids was classified as mostly, moderately and least visited if the animal raided the farm every other day to every day, once in a week and once in a month respectively. The intensity of destruction was based on the activity of the various animals on their farms as most, moderate and least destructive depending on the quantity destroyed.

\section{Results and Discussions}

Demography of the respondents

In all, there were 89 participating farmers in the research and they all responded to all the questions. The participants included $69 \%$ males and $31 \%$ females, ranging between the ages of 20 years and above. The natives were $82 \%$ and $18 \%$ were non-natives. With educational background, $19 \%$ of the respondents had no formal education, $25 \%, 30 \%$ and $26 \%$ had basic, secondary and tertiary education respectively. In terms of religion, $45 \%$ were Christians, $23 \%$ were Muslims, 22\% were Traditionalist and $10 \%$ did not belong to any religion. Most of the respondents, $51 \%$, were solely farmers; $27 \%, 19 \%$ and $3 \%$ were teachers, traders and students respectively who farmed in addition to their profession/vocation. The majority of the respondents $(40 \%)$ had their farms located at a distance greater than $4 \mathrm{~km}$ from either the National Park or the Forest Reserve; $15 \%$ had their farms at a distance between 3-4 km, and $9 \%$ had their farms at a distance between 2-3 $\mathrm{km}, 32 \%$ had their farms at a distance between $1-2 \mathrm{~km}$ and $5 \%$ had their farms at a distance less than $1 \mathrm{~km}$ from the protected areas. 


\section{Animal species most involved in crop raiding}

It was recorded that several animal species were involved in crop raiding events. The common ones were: birds, monkeys, rodents, ungulates, elephants, insects, reptiles and amphibians. Common bird species identified was the weaver bird (Ploceus cucllatus), monkeys were (Erythrocebus patas, Chlorocebus sabaeus, Papio anubis), ungulates (Cephalophus rufilatus), reptiles was Agama agama and amphibians were Bufo bufu. The birds raided in large numbers and the damage caused by monkeys was very intensive and the victims complained about the extent of the damage. Table 1 shows the percentages of respondents who indicated the frequency of animals that visited the farm and the level of their destruction. It could be deduced that among all the taxa listed, monkeys were the second most frequently farm visited animals complained of after birds by almost $60 \%$ of the respondents; yet they were the most destructive animals complained by most of the respondents. Not surprising, the three monkey species involved in the raids in this particular study have been reported to be the most destructive species reported by other researchers elsewhere (Hill, 2000; Saj et al., 2001; De Jong et al., 2008). A study in Budongo Forest Reserve in Uganda concluded that baboons could cause direct cost by damaging field crops such as maize and cassava extensively; they also cause indirect costs such as labour to protect crops and crop stands replacement (Hill, 2000). In some parts of Kenya, patas monkeys have been reported to have raided crops due to human expansion to their historical range (De Jong et al., 2008) and green monkeys (vervets) have also been reported to be involved in the conflict with farmers at forest edge of Entebbe in Uganda (Saj et al., 2001).
One of the respondents stated that, though it is not common to meet patas monkeys while human beings were on-farm they could be very destructive to farm crops. However, Hill (2000) continued that the baboons were fearless, and they were able to raid crops while human beings would be working on the farm. Almost all the respondents were amazed at the large group size of the green monkeys: it was noted that the green monkey moves in large numbers during raiding events.

Type of crops cultivated and loss to primates crop raiding

Crop cultivation was usually done on a 1-5 acre of land per household (Table 4). Majority of the victims harvested between 1-50 bags (one bag is equivalent to $125 \mathrm{~kg}$ ) of maize per farm for the season with the cost of cultivation usually amounting between GHஜC 16-800 (US\$4200) per acre. All cultivated crops (maize, groundnut, millet, beans and mango) and poultry birds were susceptible to raiding by monkeys. In almost every stage of the crop's life (from seedling to harvest), there was a possibility of attack of which every cultivated crop was vulnerable (Table 4). This was similar to the description of crop raiding by SilleroZubiri and Switzer (2001) in the Budongo forest in Uganda that, maize, right from sowing to maturity stage suffers raiding (damage). Thus, affecting the expected yield as well as incurring loss to the affected farmers. Not only were crops vulnerable but local poultry birds and their products (eggs) were highly at risk to raiding events by monkeys. At Boabeng-Fiema Monkey Sanctuary in Ghana, Wiafe and Arku (2012) reported that monkeys raided fresh eggs by consuming them but eschewed cooked ones. Majority of the respondents, $94 \%$ stated that the loss incurred as a result of monkeys raiding 
events on the local poultry cost them between GHC4-2,000 (US\$1-500) whilst that amount could have been a profit to them if the products from the poultry were sold (Table 2).

\section{The underlying causes of crop raiding by primates}

Major features of farms that were perceived to attract monkeys to raid crops included farm size, displacement of primate's habitat and nature of crop. Most respondents (71\%) attributed it to the attractiveness of crops, $14 \%$ attributed it to the replacement of monkey's habitat with farms and $16 \%$ said it might be the size of the farm.

Furthermore, $43 \%$ of the respondents were of the view that the natural food for non-human primates have become scarce; $20 \%$ indicated that crops being raided by primates were more palatable than wild food; $19 \%$ also indicated that both the taste of crop and the scarcity of primate food accounted for raiding events whilst $8 \%$ attributed the raiding to the fact that primates require diverse food items and crops were more palatable than wild food. Also, $6 \%$ stated that all the characteristics of crops attracted monkeys to raid and 4\% attributed the crop raiding only to the requirement of diverse food items by primates. Change in weather conditions (seasonal changes) affected the growth and harvesting periods of crops yet such changes do not deter monkeys from being attracted to farms. Most of the respondents (41\%) said change in harvesting period attracted monkeys to their farms, 30\% indicated that change in the fruiting period did attract monkeys to their farms and 29\% said the attraction to their farms by monkeys was based on change in the flowering period.

Other factors that were found to be the causes of monkeys' visitation to farms to raid crops were tree cutting, charcoal production, live trapping and hunting of monkeys. It was deduced that $65 \%$ of the respondents said tree cutting accounted for monkeys' raid of their crops, $18 \%$ attributed it to live trapping of monkeys, 9\% attributed it to hunting and $8 \%$ mentioned charcoal production. Even though tree cutting and hunting may seem strange to have ordinarily attracted monkeys to raid crops, these factors repel the monkeys from their natural habitat and in an effort of escaping, they chanced on the farms to raid. On the other hand, those factors deprived the monkeys of the resources required in the natural habitat and compelled them to depend on resources meant for humans. The main driving force fuelling crop raiding was basically human-induced resulting in scarcity of wild primate food. The increasing human population at the selected communities had fuelled the expansion of farms into wild areas whereby trees that could have served as a habitat for monkeys had been removed to compel the monkeys to move to farm lands and eventually raid crops.

The effect of crop raiding on livelihoods of crop raiding victims

Crop raiding by the non-human primates affect the growth performance of crops $24 \%$ of the respondents said that it reduced fruiting, $17 \%$ resulted in less fruiting and stunted growth; $17 \%$ it resulted in poor seed production and decreased fruiting of crops; $13 \%$ were of the view that crop raiding resulted in stunted growth, low fruiting and poor seed production, $10 \%$ attributed stunted growth and poor seed production to the raid and $11 \%$ of them said the raiding only affected the production of poor seed, whiles $8 \%$ attributed stunted growth to the raids (Table 3 ). 
On crop yield, $44 \%$ of the respondents showed that monkeys' crop raiding events resulted in reduction in quality whilst 38\% of the respondents reported a decrease in yield and $18 \%$ said the raiding reduced market price. Crop raiding though occurs throughout the year, it mostly occurs during the wet season with significant effect on crops' growth thereby impacting negatively on crop yield per season (Table 3).

Measures adopted by victims to mitigate crop raiding by monkeys

The high incidences of crop raiding have led to the adoption of diverse methods by victims to minimise the activity (raiding). Such methods, to the victims, were cheaper and they included shouting, beating (throwing objects at the animals), trapping and use of scarecrow. The study showed that shouting and trapping were used by $27 \%$ of the respondents to protect their crops; $20 \%$ used scarecrow and beating to deter monkeys from raiding; 15\% used shouting and scarecrow whilst $10 \%$ used only scarecrow, and $10 \%$ used only trapping. Also, $6 \%$ of the respondents combined several methods such as shouting, scarecrow, trapping and beating while $5 \%$ used shouting only and $5 \%$ beating only, and $2 \%$ use the combination of shouting and beating (Figure 2). The respondents observed that some of the methods were effective when used to protect their crops from being raided by monkeys. The following methods were declared effective by the respondents: $25 \%$ said shouting and trapping, 24\% said scarecrow and trapping, 15\% said shouting and using scarecrow, 9\% said shouting only, $8 \%$ said scarecrow only, $2 \%$ said trapping only, $2 \%$ said beating only, $2 \%$ said trapping and beating, $7 \%$ said killing the monkeys only, 3\% said none of the methods was effective whilst another
$3 \%$ of the respondents said all the methods were very effective. Some of the methods used in mitigating monkeys crop raiding have proven to be effective, $63 \%$ of the respondents indicated they would like to continue using the same method but $37 \%$ of the respondent stated that they wouldn't like to continue with their methods. Majority of the respondents (90\%) said that despite the destructive behaviour of the monkeys they would like to still have them and $10 \%$ said some form of eradication should be made to solve the raiding problem. The victims had in mind that even as they have adopted their methods especially beating the animals, these animals should also be protected.

Majority of the victims $(90 \%)$ would like to coexist with monkeys despite their destructive nature but the minority would not want to. In justifying the reasons for the respondents admitting to coexist with the monkeys, 31\% said they were God's creation and that they must live, and $20 \%$ said they were such interesting animals and one can learn a lot from them; $23 \%$ said the monkeys were their pets and were not killed for meat and $26 \%$ said they were friendly. This was not different from the views expressed by the people of Boabeng-Fiema Monkey Sanctuary where the people would like to coexist with the monkeys regardless of the intensity of destruction to their crops (Wiafe \& Arku, 2012).

Owing to the negative impact of monkeys' crop raiding events, minority of the victims $(10 \%)$ would not want to coexist with them. The reasons for some respondents who would not like to coexist with monkeys were as follows: $19 \%$ of the respondent said they just do not want to coexist with monkeys, $53 \%$ said the monkeys are dangerous and they destroy the quality of their crops, $10 \%$ also said the monkeys cause losses before harvesting 
period; $9 \%$ of the respondents said that the monkeys cause more harm than good, destroy a lot of crops and they make farming difficult, $9 \%$ were of the view that the monkeys raiding activity caused low productivity, reduce market value, and destroyed most crops leaving them with a little to depend on for a living.

\section{Conclusion and Recommendation}

It was concluded that monkeys' involvement in the crop raiding events might be because they were attracted by the crops in their victim's farms. This is probably due to the taste of the compared to the food in the wild food. Tree cutting, hunting and live trapping were found to be the main human impact influencing monkeys' raid crops. These factors might have deprived the monkeys of their natural habitat and resources. Decreased fruiting was one effect of crop raiding as well as low-quality yield. Shouting and trapping of monkeys were the most effective methods used by victims to ward off monkeys from crop raiding. The position of the farms i.e., their proximity to the forest reserve and the national park is suspected to be the main cause of the crop raiding events. Some of the raiding events can be attributed to mere chance. As monkeys forage between the two protected areas, they may come across farmlands and take advantage of them.

The following are recommended to ensure peaceful coexistence of monkeys and humans:

(i) More trees that are purposely meant for primate food should be planted in the reserves to enrich the resources to provide for the needs of monkeys to help stop or minimize raiding crop farms. (ii) People inhabiting close to reserved areas and should be educated on the benefits of coexisting with monkeys.

\section{Acknowledgements}

We would like to express heartfelt gratitude to the chiefs and people of the affected communities who received and allowed us to conduct the research in their communities.

We are also grateful to Mr. Victor Dapilah for being our interpreter and helped us to understand what the victims said. Finally, we thank Presbyterian University College, Ghana for sponsoring the research.

\section{REFERENCES}

Akenten, Z. N. W. (2015) Human-wildlife conflicts in Ghana: the case of elephants at the Mole National Park. Unpublished MSc. Thesis. Norwegian University of Science and Technology.

Allotey, A.N.M \& Wiafe E. D. (2005) Effects of land use dynamics of habitat of two sympatric primates on Boabeng-Fiema monkey sanctuary, Ghana. Ghana Journal of Science $55,3-14$.

Barnes, R. F. W. (1996) The conflict between humans and elephants in the central African forests. Mammal Review 26 (2), 67 - 80.

Christensen, G. (1992) Sensitive information: collecting data on livestock and informal credit. In: Devereux S, Hoddinott J, (eds.) Fieldwork in Developing Countries. Harvester Wheatsheaf, New York, $124-137$.

Dakwa, K. B. (2016) How does the cost of raid influence tolerance and support of local communities for a wildlife reserve? International Journal of Biodiversity and Conservation 8(4), 81 92.

De Jong, Y. A., Butynski, T. M. \& Nekaris K. A. (2008) Distribution and conservation of patas monkey (Erythrocebus patas) in Kenya. 
Journal of East African Natural History 97(1), 83 - 102.

Else, J. G. (1991) Nonhuman primates as pests. In Box, H. O. (Ed.) Primate Responses to Environmental Change, 115 - 165. London: Chapman \& Hall.

Forthman-Quick D. L, \& Demment M. W. (1988) Dynamics of exploitation: differential energetic adaptations of two troops of baboons to recent human contact. In: Fa J.E, Southwick C. H. (Eds.). Ecology and behavior of foodenhanced primate groups. New York, NY: Alan R. Liss Inc. 25 - 51.

Gillingham, S. \& Lee P. C. (2003) People and protected areas: a study of local perceptions of wildlife, crop-damage, conflict in an area bordering the Selous Game Reserve Tanzania. Oryx 37, $310-325$.

Grubb P., Jones T.S., Davies A. G., Edberg E., Starin E. D. \& Hill J. E. (1998) Mammals of Ghana, Sierra Leone and the Gambia. The Tendrine Press, Cornwall, U.K.

Hill, C. M. (2000) Conflict of interest between people and baboons: crop raiding in Uganda. International Journal of Primatology 21 (2), $299-315$.

Hill, C.M. (2004) Farmers' perspectives of conflict at the wildlife-agriculture boundary: some lessons learned from subsistence farmers. Human Dimensions of Wildlife 9, 279 - 286.

Naughton-Treves, L. (1998) Predicting patterns of crop damage by wildlife around Kibale National Park, Uganda. Conservation Biology 12 (1), $156-168$.

Naughton-Treves, L., Treves, A., Chapman, C. \& Wrangham, R. (1998) Temporal patterns of crop raiding primates: linking food availability in cropland and adjacent forest. Journal of Applied Ecology 35, 596 - 606.

Saj, T., Sicotte, P. \& Peterson, J. (2001) The conflict between vervet monkeys and farmers at the forest edge in Entebbe, Uganda. African Journal of Ecology 39, 195 - 199.

Siex, R. \& Struhsaker, T. (1999) Colobus monkeys and coconuts: a study of perceived humanwildlife conflicts. Journal of Applied Ecology 36, $1009-1020$.

Sillero-Zubiri, C. \& Switzer, D. (2001) Crop raiding primates: searching for alternative, humane ways to resolve conflict with farmers in Africa. People and Wildlife Initiative. Wildlife Conservation Research Unit, Oxford University

Wallace G. E, \& Hill C. M. (2012) Crop damage by primates: Quantifying the key parameters of crop raiding events. PLOS ONE 700, pp. 46636. Doi:101371/Journal.pone.0046636.

Warren Y, Buba B, \& Ross C. (2007) Patterns of crop-raiding by wild and domestic animals near Gashaka Bumti National Park, Nigeria. International Journal of Pest Management 53, $207-216$.

Wiafe, E. D. \& Arku, F. S. (2012) Victims' Perspectives ofLowe's Monkeys'(Cercopithecus campbelli lowe i) crop raiding events in Ghana: A case of Boabeng-Fiema Monkey Sanctuary. Journal of Biology \& Environmental Science 1, 5-8.

Wilson V. J. (1993) A zoological survey of Mole National Park, north-western Ghana. Part 1. Large mammals. Forest Resource Management Programme. Game and Wildlife Dept/ IUCN Project 9786, Accra, Ghana. 



Fig. 2: Crop raiding mitigation measures and number of respondents used.

Fig. 1: Map of the study area showing the study communities.

TABLE 1

Animals that raided crop farms and the level of destruction of crops around the Mole National Park, Ghana

\begin{tabular}{|c|c|c|c|c|c|c|}
\hline Animal & Frequency of raid & Frequency & Percentage & $\begin{array}{l}\text { Intensity of } \\
\text { destruction }\end{array}$ & Frequency & percentage \\
\hline Bird & $\begin{array}{l}\text { Mostly visit } \\
\text { Moderately } \\
\text { Least visit }\end{array}$ & $\begin{array}{l}72 \\
7 \\
10\end{array}$ & $\begin{array}{l}80.9 \\
7.9 \\
11.2\end{array}$ & $\begin{array}{l}\text { Most destructive } \\
\text { Moderate destructive } \\
\text { Less destructive }\end{array}$ & $\begin{array}{l}11 \\
14 \\
64\end{array}$ & $\begin{array}{l}12.4 \\
15.7 \\
71.9\end{array}$ \\
\hline Monkey & $\begin{array}{l}\text { Mostly visit } \\
\text { Moderately } \\
\text { Least visit }\end{array}$ & $\begin{array}{l}53 \\
27 \\
9\end{array}$ & $\begin{array}{l}59.6 \\
30.3 \\
10.1\end{array}$ & $\begin{array}{l}\text { Most destructive } \\
\text { Moderate destructive } \\
\text { Less destructive }\end{array}$ & $\begin{array}{l}59 \\
21 \\
9\end{array}$ & $\begin{array}{l}66.3 \\
23.6 \\
10.1\end{array}$ \\
\hline Rodent & $\begin{array}{l}\text { Mostly visit } \\
\text { Moderately } \\
\text { Least visit }\end{array}$ & $\begin{array}{l}37 \\
26 \\
26\end{array}$ & $\begin{array}{l}41.6 \\
29.2 \\
29.2\end{array}$ & $\begin{array}{l}\text { Most destructive } \\
\text { Moderate destructive } \\
\text { Less destructive }\end{array}$ & $\begin{array}{l}28 \\
32 \\
29\end{array}$ & $\begin{array}{l}31.5 \\
36.0 \\
32.6\end{array}$ \\
\hline Ungulates & $\begin{array}{l}\text { Mostly visit } \\
\text { Moderately } \\
\text { Least visit }\end{array}$ & $\begin{array}{l}8 \\
17 \\
64\end{array}$ & $\begin{array}{l}9.0 \\
19.1 \\
71.9\end{array}$ & $\begin{array}{l}\text { Most destructive } \\
\text { Moderate destructive } \\
\text { Less destructive }\end{array}$ & $\begin{array}{l}24 \\
15 \\
50\end{array}$ & $\begin{array}{l}27.0 \\
16.9 \\
56.2\end{array}$ \\
\hline Elephant & $\begin{array}{l}\text { Mostly visit } \\
\text { Moderately } \\
\text { Least visit } \\
\end{array}$ & $\begin{array}{l}11 \\
6 \\
72 \\
\end{array}$ & $\begin{array}{l}12.4 \\
6.7 \\
80.9 \\
\end{array}$ & $\begin{array}{l}\text { Most destructive } \\
\text { Moderate destructive } \\
\text { Less destructive }\end{array}$ & $\begin{array}{l}13 \\
14 \\
62 \\
\end{array}$ & $\begin{array}{l}14.6 \\
15.7 \\
69.7 \\
\end{array}$ \\
\hline Insects & $\begin{array}{l}\text { Mostly visit } \\
\text { Moderately } \\
\text { Least visit }\end{array}$ & $\begin{array}{l}20 \\
28 \\
41\end{array}$ & $\begin{array}{l}22.5 \\
31.5 \\
46.1\end{array}$ & $\begin{array}{l}\text { Most destructive } \\
\text { Moderate destructive } \\
\text { Less destructive }\end{array}$ & $\begin{array}{l}18 \\
27 \\
44\end{array}$ & $\begin{array}{l}20.2 \\
30.3 \\
49.4\end{array}$ \\
\hline Amphibians & $\begin{array}{l}\text { Mostly visit } \\
\text { Moderately } \\
\text { Least visit }\end{array}$ & $\begin{array}{l}8 \\
20 \\
61\end{array}$ & $\begin{array}{l}9.0 \\
22.5 \\
68.5\end{array}$ & $\begin{array}{l}\text { Most destructive } \\
\text { Moderate destructive } \\
\text { Less destructive }\end{array}$ & $\begin{array}{l}8 \\
20 \\
61\end{array}$ & $\begin{array}{l}9.0 \\
22.5 \\
68.5\end{array}$ \\
\hline Lizard & $\begin{array}{l}\text { Mostly visit } \\
\text { Moderately } \\
\text { Least visit }\end{array}$ & $\begin{array}{l}10 \\
26 \\
53\end{array}$ & $\begin{array}{l}11.2 \\
29.2 \\
59.6\end{array}$ & $\begin{array}{l}\text { Most destructive } \\
\text { Moderate destructive } \\
\text { Less destructive }\end{array}$ & $\begin{array}{l}11 \\
17 \\
61\end{array}$ & $\begin{array}{l}12.4 \\
19.1 \\
68.5\end{array}$ \\
\hline
\end{tabular}


TABLE 2

Estimated farm size and the type of crop normally cultivated by the respondents

\begin{tabular}{llllllllll}
\hline $\begin{array}{l}\text { Estimated } \\
\text { farm } \\
\text { size (acre) }\end{array}$ & Maize & Groundnut & Millet & Sorghum & Beans & Mango & Rice & Yam & Other \\
\hline $1-5$ & 54 & 58 & 67 & 80 & 60 & 79 & 66 & 66 & 88 \\
$6-10$ & 22 & 14 & 6 & 4 & 15 & 4 & 11 & 14 & 1 \\
$11-15$ & 1 & 3 & 2 & 4 & 3 & 0 & 2 & 3 & 0 \\
$16-20$ & 2 & 3 & 6 & 0 & 6 & 4 & 2 & 2 & 0 \\
$>20$ & 10 & 11 & 8 & 1 & 5 & 2 & 8 & 4 & 0 \\
Total & 89 & 89 & 89 & 89 & 89 & 89 & 89 & 89 & 89 \\
\hline
\end{tabular}

TABLE 3

Estimated cost of cultivated crops by the respondents per acre

\begin{tabular}{lllllllllll}
\hline $\begin{array}{l}\text { Estimated } \\
\text { cost }(\text { GHC) }\end{array}$ & Maize & Groundnut & Millet & Sorghum & Beans & Mango & Rice & Yam & Poultry & Others \\
\hline $1-500$ & 52 & 53 & 71 & 75 & 64 & 79 & 66 & 62 & 74 & 80 \\
$600-1050$ & 4 & 6 & 7 & 4 & 8 & 0 & 7 & 12 & 1 & 1 \\
$1050-1550$ & 2 & 5 & 6 & 0 & 0 & 0 & 1 & 2 & 0 & 1 \\
$1550-2000$ & 8 & 4 & 1 & 0 & 2 & 0 & 3 & 2 & 0 & 0 \\
$>2000$ & 23 & 21 & 4 & 10 & 15 & 10 & 12 & 11 & 14 & 7 \\
Total & 89 & 89 & 89 & 89 & 89 & 89 & 89 & 89 & 89 & 89 \\
\hline
\end{tabular}

TABLE 4

Stage of consumption of affected crops according to the respondents

\begin{tabular}{llllllllll}
\hline $\begin{array}{l}\text { Stage of } \\
\text { consumption }\end{array}$ & Maize & Groundnut & Millet & Sorghum & Beans & Mango & Rice & Yam & Others \\
\hline Flowering & 14 & 13 & 0 & 61 & 4 & 2 & 0 & 0 & 3 \\
Fruiting & 5 & 14 & 0 & 2 & 10 & 10 & 0 & 0 & 1 \\
Harvest & 15 & 13 & 3 & 7 & 4 & 0 & 2 & 5 & 79 \\
Maturity & 7 & 8 & 3 & 1 & 0 & 0 & 3 & 31 & 4 \\
Pre-mature & 5 & 0 & 63 & 2 & 50 & 76 & 76 & 45 & 0 \\
Seed & 6 & 12 & 4 & 2 & 0 & 0 & 2 & 6 & 0 \\
Seeding & 6 & 26 & 7 & 7 & 21 & 1 & 4 & 2 & 2 \\
Stem & 2 & 0 & 0 & 0 & 0 & 0 & 0 & 0 & 0 \\
Tasseling & 29 & 3 & 9 & 7 & 0 & 0 & 2 & 0 & 0 \\
Total & 89 & 89 & 89 & 89 & 89 & 89 & 89 & 89 & 89 \\
\hline
\end{tabular}

